\title{
Physalis growth, development and yield at different sowing seasons in the brazilian northeastern semiarid
}

Tamara Torres Tanan ${ }^{1}$, Alismário Leite da Silva ${ }^{1}$, Romeu da Silva Leite ${ }^{1}$, Stephanie Soares Arriero ${ }^{2}$, Marilza Neves do Nascimento ${ }^{1}$

${ }^{1}$ Universidade Estadual de Feira de Santana - UEFS, BA. ${ }^{2}$ Universidade Federal do Recôncavo da Bahia - UFRB, BA.Email: tamara.tanan@yahoo.com.br

\begin{abstract}
The Physalis genus is composed of species with economic and medicinal importance, its cultivation is expanding in Brazil, and is needed research on the performance of species in different regions of the country. Thus, the objective was to characterize the growth, development and yield of Physalis angulata and Physalis ixocarpa species cultivated in three sowing seasons in Bahia's semiarid region. The days after sowing were determined for the occurrence of vegetative and reproductive stages, and the length and diameter of the main branch were evaluated weekly. At the end of cultivation, the number and total weight of fruits per plant were determined. The plants sown in April showed the best results, as flowering precocity, higher productivity and growth close to other producing regions, which is the best period for the cultivation of species. P. angulata is a more tolerant species and can be sown at different periods without compromising yield. High temperatures combined with scarcity of rainfall compromise the development of plants of both species of Physalis.
\end{abstract}

Keywords: flowering; fruit production; Physalis angulata; Physalis ixocarpa.

\section{Crescimento, desenvolvimento e produtividade de physalis em diferentes épocas de semeadura no semiárido nordestino}

\section{Resumo}

O gênero Physalis é composto por espécies de importância econômica e medicinal e seu cultivo está em expansão no Brasil, sendo necessárias pesquisas sobre o desempenho de espécies em diferentes regiões do país. Assim, o objetivo desse trabalho foi caracterizar o crescimento, desenvolvimento e produtividade das espécies de Physalis angulata e Physalis ixocarpa cultivadas em três épocas de semeadura na região semiárida da Bahia. Os números de dias após a semeadura foram determinados para a ocorrência dos estágios vegetativo e reprodutivo, e o comprimento e o diâmetro do ramo principal foram avaliados semanalmente. Ao final do cultivo, foram determinados o número e o peso total de frutos por planta. As plantas semeadas em abril apresentaram os melhores resultados, como precocidade da floração, maior produtividade e crescimento próximo a outras regiões produtoras, sendo o melhor período para o cultivo das espécies. $P$. angulata é uma espécie mais tolerante e pode ser semeada em diferentes períodos sem comprometer o rendimento. Altas temperaturas combinadas com a escassez de chuvas comprometem o desenvolvimento das plantas de ambas as espécies de Physalis.

Palavras-chave: floração; produção de frutos; Physalis angulata; Physalis ixocarpa.

\section{Introduction}

The Physalis genus is widely distributed throughout the Americas and its species stand out for the production of sweet fruits rich in vitamin $\mathrm{C}$ and secondary metabolites with great medicinal and pharmacological activity (LIMA et al., 2010). In Brazil, there are eight species distributed throughout the country (STEHMANN 
et al., 2015). Physalis angulata $\mathrm{L}$. is a wild species of great popularity in the North and Northeast, standing out as the most representative considering the medicinal value.

Regarding fruit growing, the species Physalis ixocarpa Brot. has great highlight. Originally from Mexico, it is a constituent of the diet of much of Central America, with large fruits that are mainly used in the preparation of sauces (CURI et al., 2018; MEDINA-MEDRANO et al., 2015). Due to the great potential of these species, many researches are being developed, mainly related to pharmacological activity and fruit quality. With the expansion of the market, studies are necessary to insert the cultivation of the other species of the genus, to develop more profitable cultivation technologies, as well as to characterize the growth and development of plants under specific climate conditions (MUNIZ et al., 2015).

The characterization of a plant development requires knowledge of the phenological cycle and may help in choosing the ideal time for cultivation, especially in the production of fruit that is considered annual, such as physalis. The sowing and transplanting season are important factors, and should allow the cultivation in the most favorable period, in terms of water availability, heat and light, and the growth and development of the plants, thus ensuring lower risk to producers and financial agents who invest in crop cultivation (PEIXOTO et al., 2000). Knowledge of flowering and maturation seasons is also important, as they may vary by year and place (SMOLARZ, 2006).

Little is known about the cultivation of physalis species in Brazil, especially in the semiarid region. Thus, the objective of this work was to characterize the growth, the phenological stages, yield and to determine the most appropriate sowing time for $P$. angulata and $P$. ixocarpa plants cultivated in Bahia semiarid.

\section{Material and methods}

The experiment was carried out in State University of Feira de Santana (UEFS), Bahia, Brazil (12 $14^{\prime} 21^{\prime \prime} \mathrm{S} ; 38^{\circ} 58^{\prime} 46^{\prime \prime}$, at 258 asl), during the period April 2013 to September 2014. The location belongs to the semiarid region (BRAZIL, 2004) and according to the Köppen classification, the region's climate is warm and (Am) and has an average annual rainfall of $848 \mathrm{~mm}$ and an average annual temperature of $24{ }^{\circ} \mathrm{C}$ (DINIZ et al., 2008).

$P$. angulata and $P$. ixocarpa plants were obtained by sowing in polypropylene disposable cup containing the commercial substrate Biomix $^{\circledR}$, being placed two seeds per cup, and kept in a greenhouse with daily sprinkler irrigation. Transplantation to the experimental field was performed when the seedlings were about $20 \mathrm{~cm}$ long. The experiment was conducted in a randomized block design, containing 80 plants per species arranged in 4 blocks, with spacing of $1 \mathrm{~m}$ between plants and $1.5 \mathrm{~m}$ between rows. The fertilization was performed according to the recommendation for P. angulata (TANAN et al., 2013). Cultural practices were performed when necessary.

Climatological data for the experiment period were obtained at UEFS Climatological Station, $9 \mathrm{~km}$ from the experiment site. Rainfall in the region is usually concentrated over three months, with greater rainfall in May, June and July. The months from January to March are characterized by less precipitation, with a risk of drought. The highest temperatures are observed in summer and the lowest in June and July (Figure 1).

The evaluations were carried out in plants from three crops, sown in different periods: April/2013, December/2013 and June/2014. For the characterization of the phenological stages, branches were marked in randomly chosen plants, to observe the occurrence of the following stages: 1 - true leaves: plants with true leaves fully expanded and approximately $20 \mathrm{~cm}$ long, being able to transplant; 2 - flower buds: plants with prominent buds, the corolla protrudes from the calyx; 3 - open flowers: plants with flowers in two stages, with the corolla partially or completely open; 4 - immature fruits: plants with fruit emergence, still in ripening stage; 5 - ripe fruits: fruits with chalice coloration from brownish yellow to $P$. angulata and light green to $P$. ixocarpa, when they were ready for harvest. Evaluations were performed weekly and determined on days after sowing (DAS). 
Figure 1. Minimum, average and maximum monthly air temperature and rainfall variations from January 2013 to October 2014. Climatological Station/UEFS, Feira de Santana, BA, 2015.

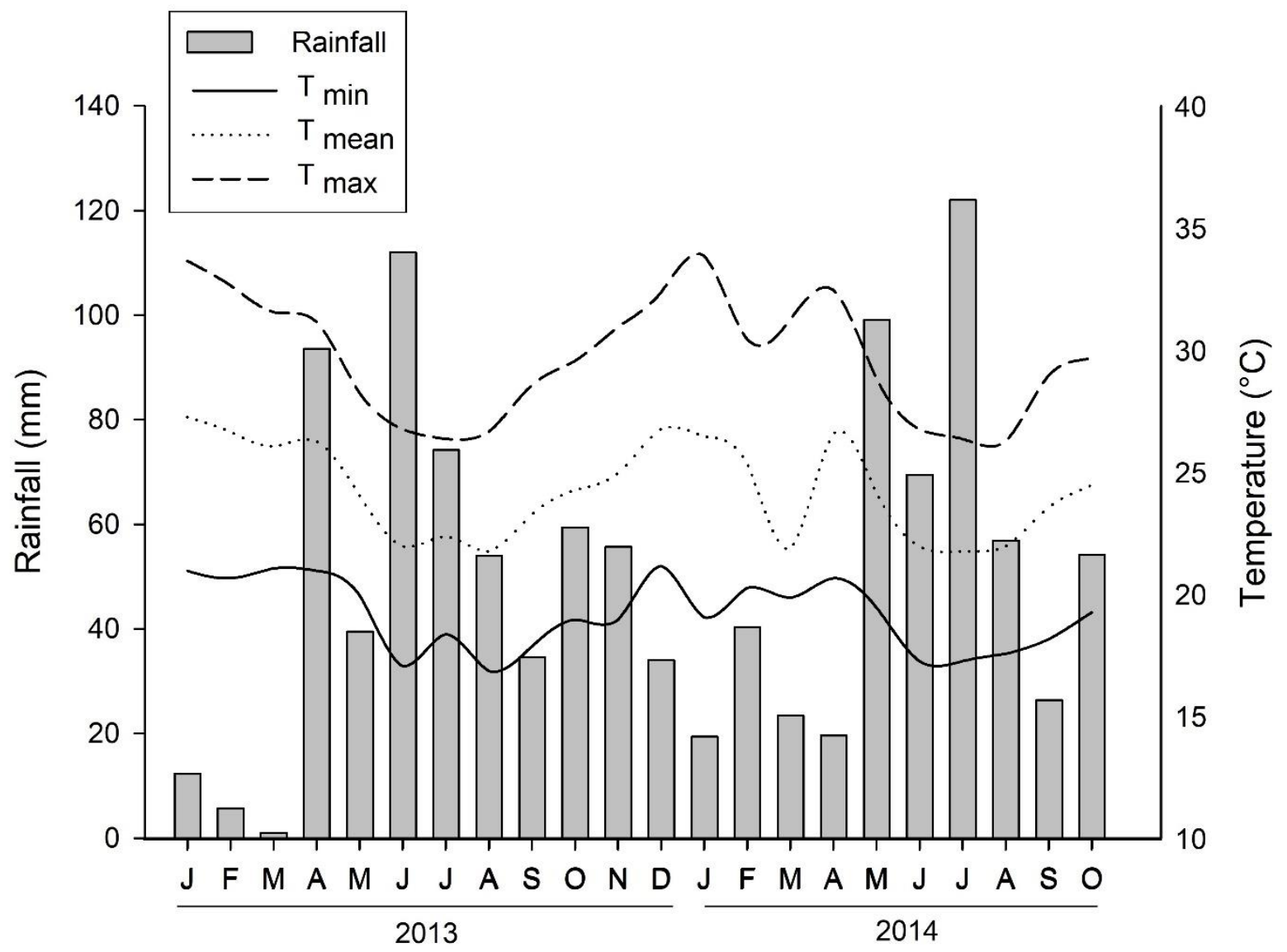

Weekly, for growth and yield evaluation, the shoot height $(\mathrm{cm})$, was determined from the ground level, with the aid of a tape measure; and the diameter of the main branch $(\mathrm{mm})$, verified at a height of $5 \mathrm{~cm}$ above ground level, using a digital caliper. At the end of cultivation, fruits were collected to determine fruit weight $(\mathrm{g})$ and total number of fruits per plant.

In order to describe the variability observed in the data regarding plant height, stem diameter, number and weight of fruits, the mean and standard error of the mean were used.

\section{Results and Discussion}

The different developmental stages of plants Physalis angulata and Physalis ixocarpa are shown in Figure 2.

Plants from sowing in April/2013 and June/2014 had all their development completed, while plants sown in December/2013 did not survive, so this sowing time was disregarded for the analyzes. Summer in Bahia's semiarid region is characterized by high temperatures, higher than $30{ }^{\circ} \mathrm{C}$, and low rainfall, factors that together with oxygen are the most limiting to the initial development of the plant (MARCOS FILHO, 2015); this may have led to high mortality among the plants evaluated during this period. 
Figure 2. Different phenological stages of Physalis angulata (A) e Physalis ixocarpa (B). 1 - True leaves (suitable for transplantation), 2 - flower buds, 3 - open flower, 4 - immature fruits, 5 - ripe fruits (crop).

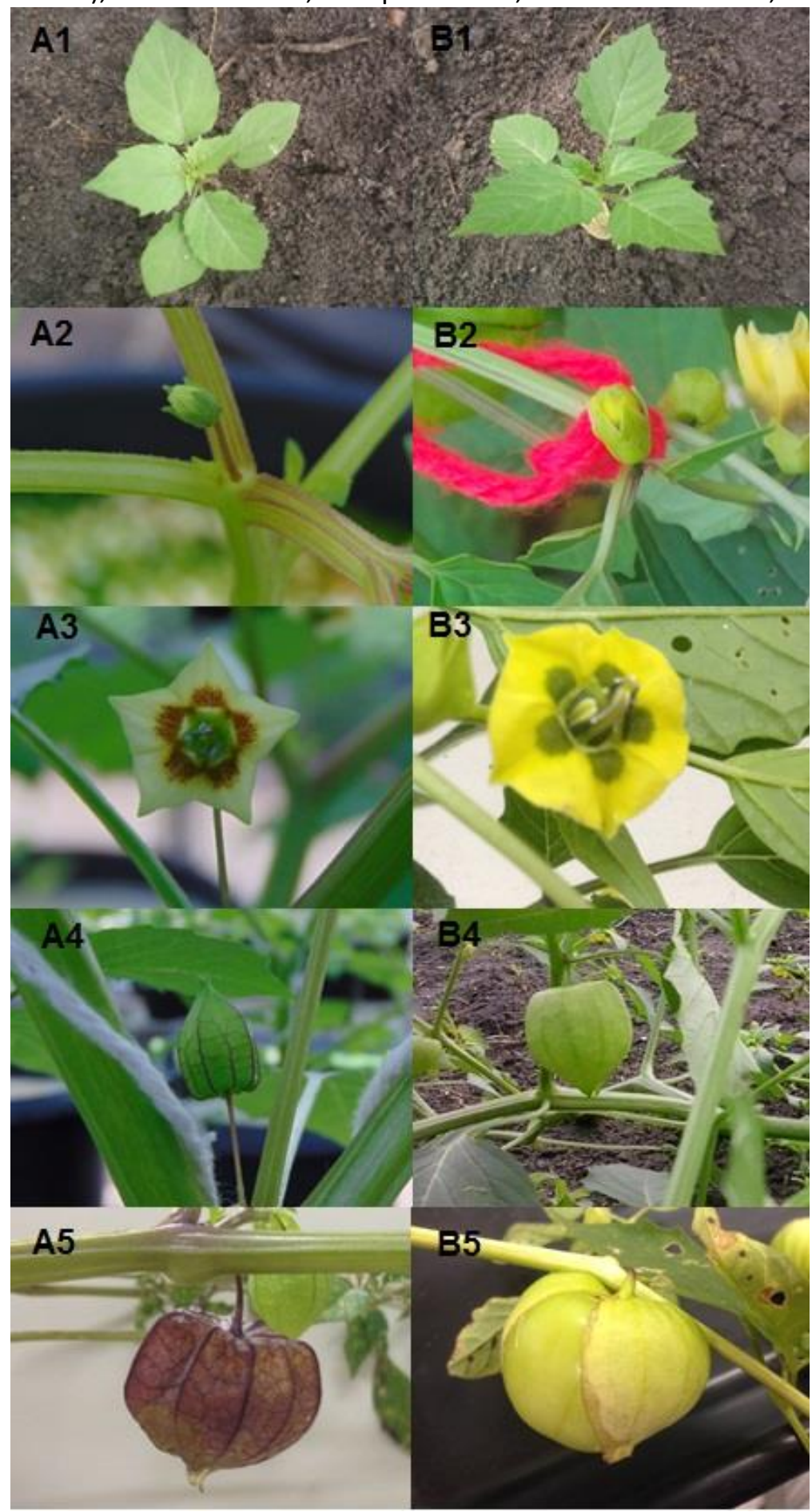

The plants of $P$. angulata and $P$. ixocarpa reached $20 \mathrm{~cm}$ in length, being able to transplant, with the same period between the two crops, and completed their development cycle, with crop in 94 DAS when sown in April and 80 DAS in June (Table 1; Figure 3A and B).

Comparing the two sowing periods of $P$. angulata plants it was observed that in April/2013 cultivation, flowering was anticipated, with flower buds appearing nine days before the occurrence of June/2014. Despite the smaller difference in days, early flowering in April cultivation also occurred in $P$. ixocarpa plants (Table 1). Both sowing periods presented distinct climatic characteristics, winter in the semiarid is characterized by a decrease in temperature, which is one of the factors of direct influence on flowering. In studies with other Solanaceae, 
Kalbarczyk and Kalbarczyk (2010) and Kalbarczyk et al. (2011) observed the anticipation of flowering in potatoes and tomatoes to an increase of $1{ }^{\circ} \mathrm{C}$, similar to that in this study, in which the $2{ }^{\circ} \mathrm{C}$ increase in average temperature between the two Cropping seasons, reduced the number of days to reach the reproductive phase in the evaluated species.

Table 1. Number of days after sowing (DAS) required for Physalis angulata and Physalis ixocarpa plants to reach each stage of development as a function of sowing dates.

\begin{tabular}{ccccccc}
\hline \multirow{2}{*}{ Sowing dates } & \multicolumn{7}{c}{ Stage of development ${ }^{1}$} \\
& 1 & 2 & 3 & 4 & 5 \\
\hline Physalis angulata & & & & & \\
$(04 / 19 / 2013)$ & 28 & 35 & 48 & 55 & 94 \\
$(12 / 02 / 2013)$ & 36 & - & - & - & - \\
$(06 / 04 / 2014)$ & 27 & 44 & 55 & 58 & 80 \\
Physalis ixocarpa & & & & & \\
$(04 / 19 / 2013)$ & 28 & 35 & 41 & 57 & 93 \\
$(12 / 02 / 2013)$ & 36 & - & - & - & - \\
$(06 / 04 / 2014)$ & 27 & 38 & 44 & 58 & 82 \\
\hline
\end{tabular}

${ }^{1} 1$ - Able to transplant, 2 -flowers buds, 3 - open flower, 4 - immature fruits, 5 - ripe fruits (crop).

From the beginning of fruiting to maturation of $P$. angulata fruits were 39 days for plants sown in April/2013 and 22 days for June/2014. Similar to that observed for $P$. ixocarpa plants, with a difference of 12 days between the beginning of fruiting and fruit maturation, comparing the two crops (Table 1). In both species and sowing periods, harvesting can be performed between 80-90 days, as also described by Rivera (2004) for Physalis philadelphica. According to the technical bulletin for the cultivation of uchuva (Physalis peruviana) in Colombia, from transplantation to first harvest occurs on average 90 days, where the average temperatures are approximately $20{ }^{\circ} \mathrm{C}$ (ZAPATA et al., 2002).

Temperature is a determining factor for many physiological events during plant development, and is directly related to their qualitative properties, such as the sugar content in fruits (MATTIUZ, 2007). The cultivation carried out in April/2013 was characterized by sowing at higher temperatures which decreased throughout the cultivation, the opposite of the cultivation started in June/2014, where sowing occurred in the lower temperature month, with increase over the cultivation. This fact influenced the number of days needed for fruit ripening. According to Mattiuz (2007), for most fruits and vegetables, the higher the temperature during their development period, the harvest is more anticipated.

P. ixocarpa plants from sowing in June/2014 had a $45.3 \%$ reduction in maximum height compared to those sown in April 2013, and $37.5 \%$ by analyzing stem base diameter (Figure 3B). This reduction can be attributed to temperature differences between cultivation periods. According to Filgueira (2013), low temperatures can affect growth and development performance, causing shortening of the internodes and reduction of tomato plant size. However, this behavior was not observed for $P$. angulata plants, the lower temperatures during the second sowing accelerated growth in height and diameter of the stem, although at the end of the crops both had similar height and diameter (Figure 3A).

The two species evaluated increased in height throughout cultivation, mainly in the first 50 days. According to Miranda (2005), Physalis plants when grown under favorable temperature and humidity conditions $\left( \pm 20{ }^{\circ} \mathrm{C}\right.$ and $\pm 70 \%$, respectively) have the characteristic of rapid increase in height in the early periods, followed by reduction due to the formation of flowers and fruits. These act as new drains and require a larger amount of photosynthetic products for their growth, with a redirection of photoassimilates that were previously intended for growth in part vegetative. 
Figure 3. Plant height and diameter of steam base of Physalis angulata (A) e Physalis ixocarpa (B) plants throughout development at different sowing dates. Feira de Santana, BA, 2015.
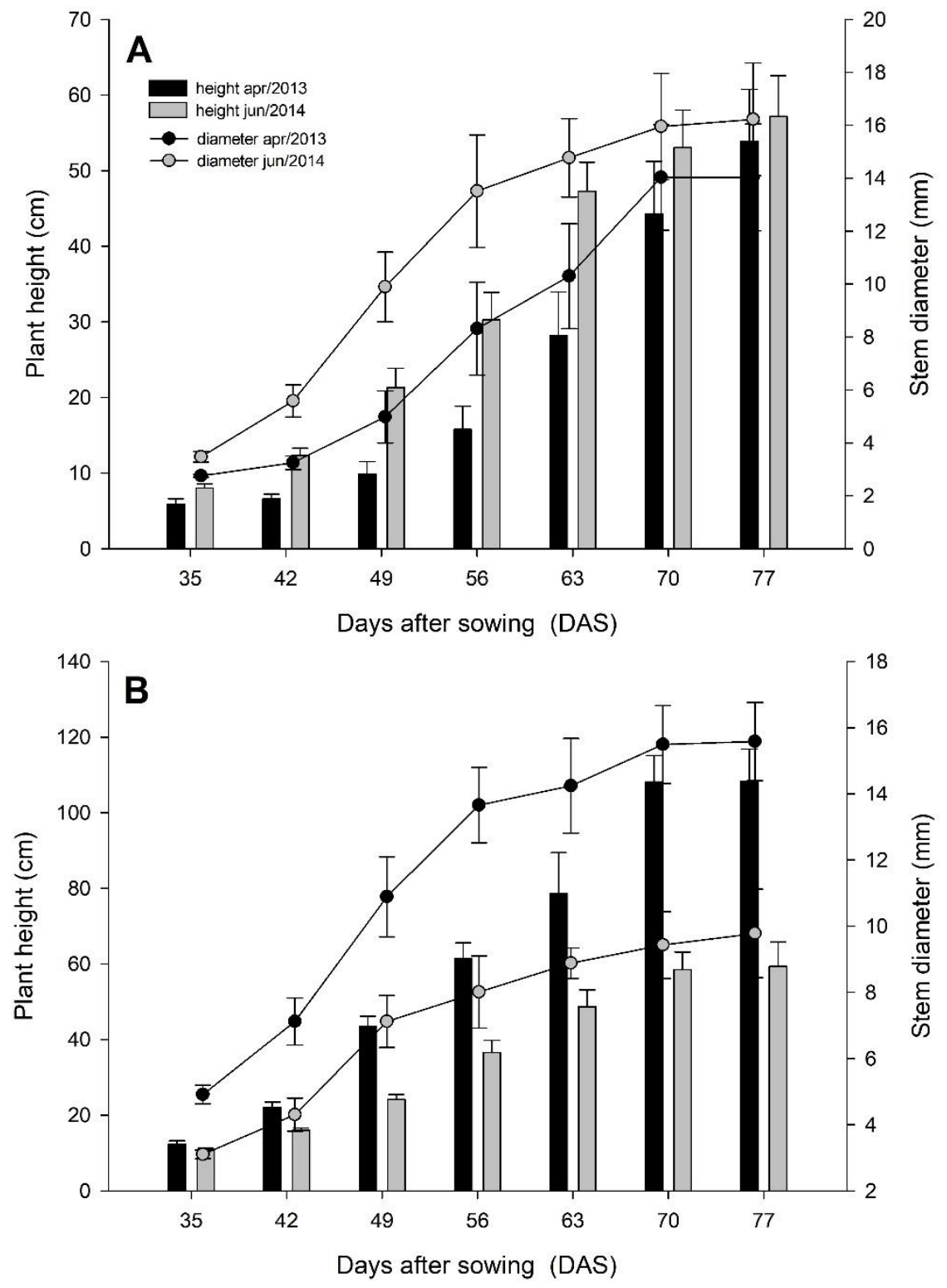

Considering the yield, $P$. angulata plants presented similar number of fruits between the two cultivation periods (Table 2). Regarding the average fruit weight, the results were superior to those obtained by Thomé et al. (2010) in Paraná (1.44 g / fruit) and Santiago et al. (2019) in Pará (1.8 g / fruit), and lower than that observed by Oliveira et al. (2011) in the Amazon (4,33 g / fruit). Different situation was observed for $P$. ixocarpa plants that were influenced by the period in which sowing occurred. In the cultivation started in June there was a reduction in the number of fruits per plant and also in the average fruit weight (Table 2). The species $P$. ixocarpa has no occurrence in Brazil, however, it has economic importance in the international market, and in Mexico, the main producer, the average fruit weight varies between 23 and $37 \mathrm{~g}$ according to cultivar (BURGOS et al., 2011).

Table 2. Number of fruits per plant and average fruit weight of Physalis angulata and Physalis ixocarpa cultivated at different sowing dates.

\begin{tabular}{|c|c|c|}
\hline Sowing dates & $\begin{array}{l}\text { Number de } \\
\text { fruits/plant }\end{array}$ & $\begin{array}{l}\text { Average fruit } \\
\text { weight (g) }\end{array}$ \\
\hline \multicolumn{3}{|c|}{ Physalis angulata } \\
\hline$(04 / 19 / 2013)$ & $167.4 \pm 35.1$ & $2.5 \pm 0.08$ \\
\hline$(06 / 04 / 2014)$ & $155.2 \pm 35.2$ & $2.1 \pm 0.1$ \\
\hline \multicolumn{3}{|c|}{ Physalis ixocarpa } \\
\hline$(04 / 19 / 2013)$ & $83 \pm 11.9$ & $43.6 \pm 3.8$ \\
\hline$(06 / 04 / 2014)$ & $22.5 \pm 4.2$ & $24.67 \pm 1.8$ \\
\hline
\end{tabular}


The yield reduction observed in the second crop in $P$. ixocarpa plants may indicate more sensitivity of this species to excess rainfall, since for this period a higher rainfall index was registered for the semiarid region of Bahia. Intense rainfall can lead to flowers abortion, besides favoring disease incidence, and impair nutrient absorption by decrease plant transpiration (GUIMARÃES et al., 2007). The smaller number of fruits is also related to the smaller size of the plants obtained in this crop.

The results obtained for $P$. angulata are in line with those recommended for other solanaceous crops in the region (SILVA et al., 2006). Despite the anticipation of harvesting in plants from June sowing, in both growing periods, $P$. angulata plants showed similar growth and yield, indicating its greater adaptation to local conditions, probably because it is a naturally occurring species in the state of Bahia (MATOS, 2007).

Since it is not a naturally occurring species in Brazil and is unknown to most national consumers, there are no studies evaluating the development of $P$. ixocarpa plants in the various regions of the country. However, these results show that its cultivation is possible in the semiarid state of Bahia, being necessary studies of proper management of the crop, such as fertilization, tutoring, way, pruning, among other cultural practices aiming at increased productivity and quality fruits.

\section{Conclusion}

Physalis angulata and Physalis ixocarpa plants have a cultivation cycle between 80 and 94 days. Sowing of these species should preferably be done in the fall, favoring the development and yield of the species. $P$. angulata is a more tolerant species and can be sown at multiple periods without compromising yield. However, high temperatures $\left( \pm 30{ }^{\circ} \mathrm{C}\right)$ combined with rainfall shortages compromise plant development of both species, planting in these conditions is not recommended.

\section{Acknowledgement}

This study was financed in part by the Coordenação de Aperfeiçoamento de Pessoal de Nível Superior - Brasil (CAPES) - Finance Code 001. The authors thank the Fundação de Amparo à Pesquisa do Estado da Bahia (FAPESB) for financial support.

\section{References}

BRASIL. Ministério da Economia. Secretaria Especial de Fazenda. Portaria Interministerial $\mathbf{N}^{\circ}$ 6, 29 de março, 2004. Brasília, DF: Ministério da Economia, 2004.

BURGOS, A. R.; AYALA-GARAY, O. J.; LIVERA, A. H.; LEAL-LEÓN, V. M.; CORTEZ-MONDACA, E. Desarrollo de fruto y semilla de cinco variedades de tomate de cáscara en Sinaloa. Revista Mexicana de Ciencias Agrícolas, v. 2, n. 5, p. 673687, 2011.

https://doi.org/10.29312/remexca.v2i5.1617

CURI, P. N.; CARVALHO, C. S.; SALGADO, D. L.; PIO, R.; SILVA, D. F.; PINHEIRO, A. C. M.; SOUZA, V. R. Characterization of different native american physalis species and evaluation of their processing potential as jelly in combination with brie-type cheese. Food Science and Technology, v. 38, n. 1, p. 112-119, 2018.

http://dx.doi.org/10.1590/1678-457x.01317

DINIZ, A. F.; SANTOS, R. L.; SANTO, S. M. Avaliação dos riscos de seca para o município de Feira de Santana-BA associado à influência do el niño no semi-árido do nordeste brasileiro. Geografia's, v. 1, p. 18-24, 2008

FILGUEIRA, F. A. R. Novo manual de olericultura: agrotecnologia moderna na produção e comercialização de hortaliças. 3rd edition. Viçosa: UFV Publisher, 2013.

GUIMARÃES, M. de A.; CALIMAN, F. R. B.; SILVA, D. J. H.; FLORES, M. P.; ELSAYED, A. Y. A. M. Exigências climáticas da cultura do tomateiro. In: SILVA, D. J. H.; VALE, F. X. R. (eds.) Tomate: tecnologia de produção. Visconde do Rio Branco: Suprema Printing and Publishing, 2007. p. 85-99.

KALBARCZYK, E.; KALBARCZYK, R. The course phenological phases of potato and its determination by multi-annual variability of air temperature in Poland. Annales UMCS, v. 65, n. 4, p. 1-11, 2010.

http://dx.doi.org/10.2478/v10081-010-0032-y

KALBARCZYK, R.; RASZKA, B.; KALBARCZYK, E. Variability of the course of tomato growth and development in poland as an effect of climate change. In: BLANCO, J.; KHERADMAND, H. (eds.) 
Climate Change - Socioeconomic Effects. InTech, 2011. p. 279-306. https://doi.org/10.5772/24235

LIMA, C. S. M.; GONÇALVES, M. A.; TOMAZ, Z. F. P.; RUFATO, A. R.; FACHINELLO, J. C. Sistemas de tutoramento e épocas de transplante de physalis. Ciência Rural, v. 40, n. 12, p. 2472-2479, 2010. http://dx.doi.org/10.1590/S0103$\underline{84782010001200006}$

MATTIUZ, B. Fatores da pré-colheita influenciam a qualidade final dos produtos. Visão Agrícola, v. 7, p. 18-21, 2007.

MATOS, F. J. A. Plantas medicinais: guia de seleção e emprego de plantas usadas em fitoterapia no Nordeste do Brasil. 3. ed. Fortaleza: UFC Publisher, 2007.

MARCOS FILHO, J. Fisiologia das sementes de plantas cultivadas. Londrina: ABRATES, 2015.

MEDINA-MEDRANO, J. R.; ABARCA, N. A.; GONZALEZ-ELIZONDO, M. S.; URIBE-SOTO, J. N.; GONZZLEZ-VALDEZ, L. S.; ARRIETA, Y. H. Phenolic constituents and antioxidant properties of five wild species of Physalis (Solanaceae). Botanical Studies, v. 56, n. 1, p. 24-37, 2015. http://dx.doi.org/56,24.10.1186/s40529-015010-y

MIRANDA, D. Criterios para el establecimiento, los sistemas de cultivo, el tutorado y la poda de la uchuva. In: FISCHER, G.; MIRANDA, D.; PIEDRAHITA, W.; ROMERO, J. (eds.) Avances en cultivo, poscosecha y exportación de la Uchuva (Physalis peruviana L.) en Colombia. Bogotá: Universidad Nacional de Colombia, 2005. p. 2953.

MUNIZ, J.; MARCHI, T.; COLDEBELLA, M. C.; RUFATO, L.; KRETZSCHMAR, A. A. Crescimento vegetativo e potencial produtivo de fisális. Revista de Ciência Agroveterinária, v. 14, n. 1, p. 15-23, 2015.

OLIVEIRA, J. A. R.; MARTINS, L. H. S.; VASCONCELOS, M. A. M.; PENA, R. S.; CARVALHO, A. V. Caracterização física, físico-química e potencial tecnológico de frutos de camapu (Physalis angulata L.). Revista Brasileira de Tecnologia Agroindustrial, v. 5, n. 2, p. 573-583, $2011 . \quad \quad$ http://dx.doi.org/10.3895/S1981$\underline{36862011000200009}$
PEIXOTO, G. P.; CÂMARA, G. M. S.; MARTINS, M. C.; MARCHIORI, L. F. S.; GUERZONI, R. A.; MATTIAZZI, P. Épocas de semeadura e densidade de plantas de soja: I. Componentes de produção e rendimento de grãos. Scientia Agrícola, v. 57, n. 1, p. 47-61, 2000.

http://dx.doi.org/10.1590/S0103$\underline{90162000000100015}$

RIVERA, L. L O. Caracterización agromorfológica de 36 accesiones de miltomate Physalis philadelphica Lam. en el municipio de Chimaltenango. Monograph, Faculdade San Carlos de Guatemala, Guatemala, 2004.

SANTIAGO, W. S.; GAMA, J. S. N.; TORRES, S. B. BACCHETTA, G. Physiological maturity of Physalis angulata L. seeds. Revista Ciência Agronômica, v. 50, n. 3, p. 431-438, 2019. https://doi.org/10.5935/1806-6690.20190051

SILVA, J. B. C.; ELÓI, M. A. A.; PARMAGNANI, R. M.; ARAÚJO, G. C. S. Cultivo do tomate para industrialização. 2. ed. Brasília, DF: Sistema de Produção, Embrapa Hortaliças (Online), 2006.

SMOLARZ, K. Evaluation of four blueberry cultivars growing in Central Poland. Acta Horticultural, v. 715, n. 9, p. 81-84, 2006.

http://dx.doi.org/10.17660/ActaHortic.2006.715. $\underline{9}$

STEHMANN, J. R.; MENTZ, L. A.; AGRA, M. F.; VIGNOLI-SILVA, M.; GIACOMIN, L.; RODRIGUES, I. M. C. Solanaceae. In: Lista de Espécies da Flora do Brasil. Rio de Janeiro: Jardim Botânico do Rio de Janeiro, 2015.

TANAN, T. T.; NASCIMENTO, M. N.; PASSOS, A. R.; LEITE, R. S.; GUIMARÃES, D. S. Physalis angulata L. cultivada sob níveis de adubação NPK. Magistra, v. 25, p. 378-379, 2013.

THOMÉ, M.; OSAKI, F. Adubação de nitrogênio, fósforo e potássio no rendimento de Physalis spp. Revista Acadêmica: Ciências Agrárias e Ambientais, v. 8, n. 1, p. 11-18, 2010.

http://dx.doi.org/10.7213/cienciaanimal.v8i1.103 $\underline{64}$

ZAPATA, J. L.; SALDARRIAGA, A.; LONDOÑO, M.; DIAZ, C. Manejo del cultivo de la uchuva em Colombia. Antioquia: Corporación Colombiana de Investigación Agropecuaria, 2002. 